\title{
Schistosomotic choroiditis.
}

\section{Funduscopic changes and differential diagnosis}

\author{
FERNANDO ORÉFICE,' CARLOS JORGE RODRIGUES SIMAL,' AND \\ JOSÉ EYMARD HOMEM PITTELLA ${ }^{2}$
}

From the 'Service of Uveitis and the ${ }^{2}$ Division of Neuropathology, Federal University of Minas Gerais, Medical School, Belo Horizonte, Minas Gerais, Brazil

SUMMARY This paper presents the results of biomicroscopy and funduscopy on five patients with hepatosplenic schistosomiasis mansoni. Fluorescein angioretinography was performed on two patients. All cases showed yellowish white multiple billateral nodules of various sizes, located in the choroidal plane. The nature and differential diagnosis of these nodules is discussed, and the suggestion is made that they represent cases of schistosomotic nodular choroiditis.

Schistosomiasis (Schistosoma mansoni, S. haematobium, and $S$. japonicum) is a worldwide public health problem, affecting approximately 200 million people, with roughly 10 million cases in Brazil.' $S$. mansoni is the most widely distributed species, present in the Caribbean Isles, South America, Africa, and Arabia, with widespread geographical extension and an increase in prevalence..$^{23}$

The $S$. mansoni hepatosplenic form of the disease is both common and has serious consequences. In Brazil it affects 3 to $12 \%$ of patients with schistosomiasis. ${ }^{45}$ The parasite has unusual locations in the hepatosplenic form of the disease, with $26 \%$ of the patients presenting with cerebral parasites. ${ }^{6}$

During funduscopic examination of a child with hepatosplenic schistosomiasis Oréfice in 1968 observed ${ }^{7}$ yellowish white nodules of various sizes in the choroid in both eyes. This finding suggested the possibility of involvement of the uveal tract, as in cysticercosis. Further examinations of 50 patients with hepatosplenic schistosomiasis revealed four cases with similar choroidal changes.

The recent finding of schistosomotic granulomas in the choroid of a patient with hepatosplenic schisotosomiasis ${ }^{8}$ confirms the impression that these ophthalmic changes were caused by that disease, a condition not so far described.

\section{Case reports}

CASE 1 (Neves et al., 1978) ${ }^{7}$

This case has been reported on by Neves et al. ${ }^{7}$ It is of Correspondence to Dr Fernando Oréfice, Rua Espírito Santo 1634, apto. 102, 30.000 Belo Horizonte, MG, Brazil. a girl aged 9 years, white, admitted to hospital in 1968.

Physical examination. Porta-caval type of collateral circulation. Liver palpable at $4 \mathrm{~cm}$ below the costal margin. Spleen palpable at $2 \mathrm{~cm}$ below the right costal margin and $8 \mathrm{~cm}$ under the xiphoid.

Laboratory tests. Stool examination showed viable

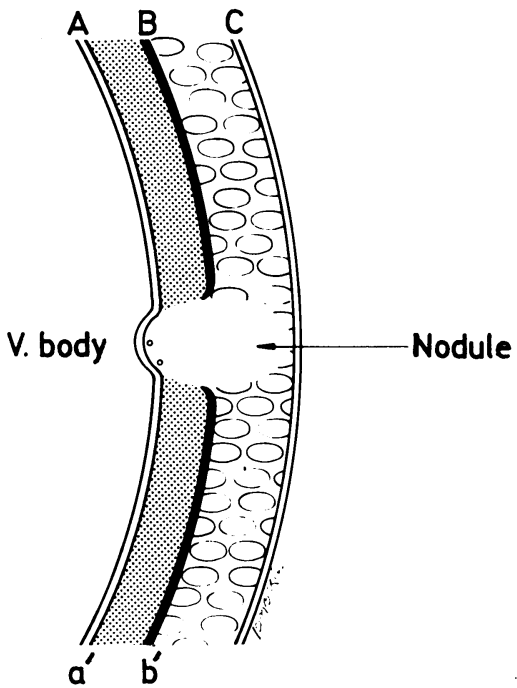

Fig. 1 Drawing of optic section of a nodule. The anterior retina profile line $\left(\mathrm{a}^{\prime}\right)$ projects slightly towards the vitreous body; there is discontinuity of the posterior retina profile line ( $\left.b^{\prime}\right)$. Translucent tissue is observed in the retina and choroid. $\mathrm{A}=$ Internal limiting membrane. $\mathrm{B}=$ Pigment epithelium. $\mathrm{C}=$ Sclera. $\mathrm{a}^{\prime}=$ Anterior retina profile line. $\mathrm{b}^{\prime}=$ Posterior retina profile line. 


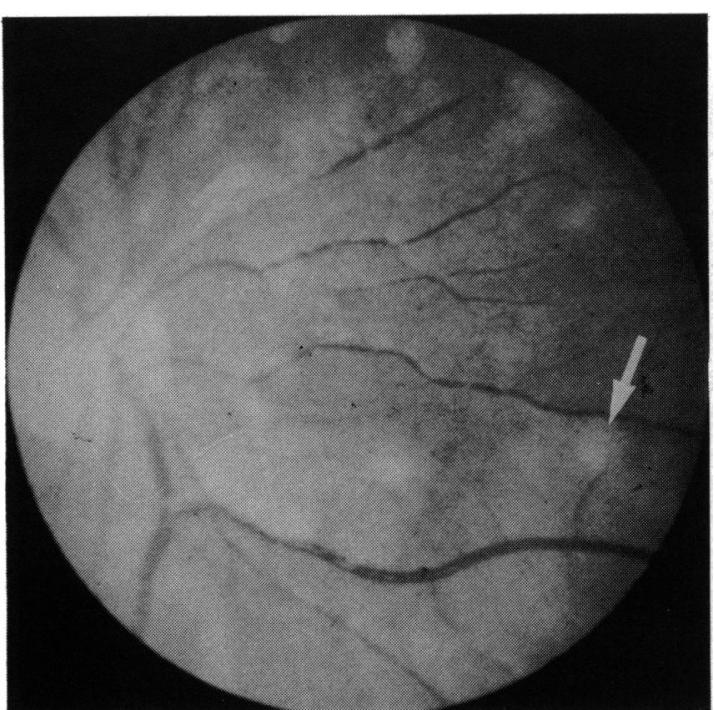

Fig. 2 Case 1: right eye, with multiple whitish nodules, one arrowed.

$S$. mansoni ova. Mantoux test positive at 1:100000. Chest $x$ ray showed disseminated micronodules in both lungs and an increase in cardiac area. Electrocardiogram showed right ventricular overload.

Eye examination. Right eye, visual acuity 20/60 with no correction; left eye, 20/20. Intraocular pressure was $13 \mathrm{mmHg}$ in both eyes. With the Goldmann-Busacca contact lens the vitreous body appeared free of inflammatory cells, even close to fundus lesions. An optic section of the nodules (Fig. 1) showed a projection of the anterior profile of the retina towards the vitreous body, and discontinuity of the posterior profile of the retina, as evidence of the lack of pigmented retinal epithelium. Indirect binocular ophthalmoscopy (Fig. 2, right eye) of both eyes disclosed the presence of numerous yellowish white translucent nodules of various sizes, distributed irregularly, but with some concentration close to the optic nerve and blood vessels. The veins were moderately engorged, and the maculae were normal.

\section{CASE 2}

A 14-year-old female, of mixed colour, was admitted to hospital in 1978.

Physical examination. Liver palpable at $12 \mathrm{~cm}$ below the costal margin on the hemiclavicular right line and $16 \mathrm{~cm}$ below the xiphoid, with a blunt edge, not painful, with a micronodular surface. Spleen palpable at $4 \mathrm{~cm}$ below the left costal margin on the left hemiclavicular line, with a blunt edge, not painful.

Laboratory tests. Tuberculin test was not reactive.

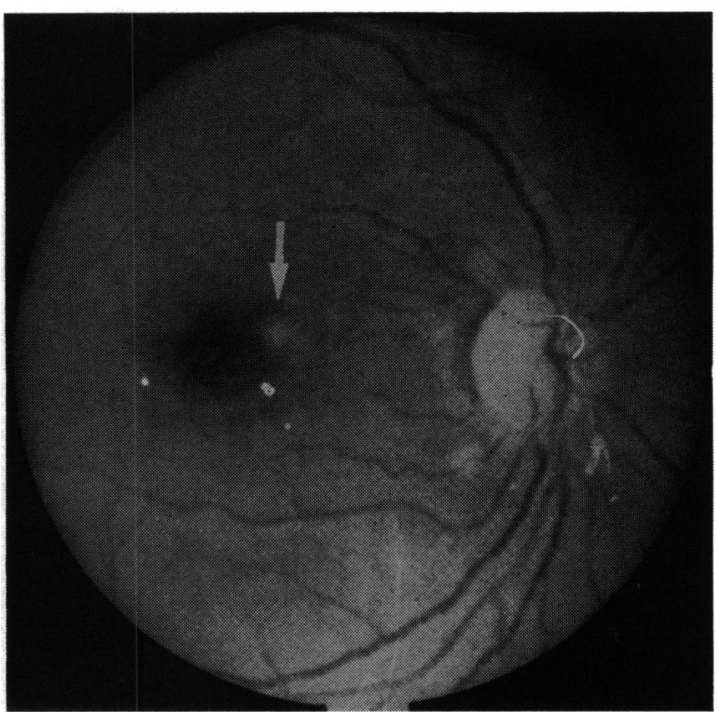

Fig. 3 Case 2: right eye, with whitish medium sized nodules close to the optic nerve; one perifoveal nodule (arrow).

Stool examination showed viable $S$. mansoni ova. Electrocardiogram showed right ventricular overload and diffuse ischaemia. An oesophagogram showed oesophageal varices. A chest $x$ ray showed enlarged heart, mainly the right ventricle; diffuse micronodules in both lungs. Haemodynamic tests showed hypertension in right chambers and slight hypertension in left chambers. Hepatic biopsy showed granulomas suggesting schistosomotic origin. Lung biopsy showed granulomas with $S$. mansoni ova.

Eye examination. Visual acuity in both eyes was $20 / 20$. Intraocular pressure in both eyes was 15 $\mathrm{mmHg}$. Anterior chamber biomicroscopy showed no inflammatory cells. Vitreous body biomicroscopy showed rare cells. With the Goldmann-Busacca contact lens the vitreous body disclosed rare inflammatory cells and occasional nodules with a similar aspect to those in case 1 . Indirect binocular ophthalmoscopy of both eyes (Figs. 3 and 4, right eye) revealed yellowish white nodules of various sizes distributed irregularly, with greater concentration around the optic nerve in the right eye. Fluorescein angioretinography of the right eye (Figs. $5 \mathrm{~A}$ and $\mathrm{B}$, right eye) showed hyperfluorescent nodules in the posterior pole appearing in early phases, with no leakage in late phases. The left eye presented similar findings.

\section{CASE 3}

This was a man aged 35 years, of mixed colour, admitted to hospital in 1979. He had been treated for schistosomiasis with hycanthone five years before, 
Fig. 4 Case 2: right eye, composite fundus with green filter, showing nodule distribution (arrows).

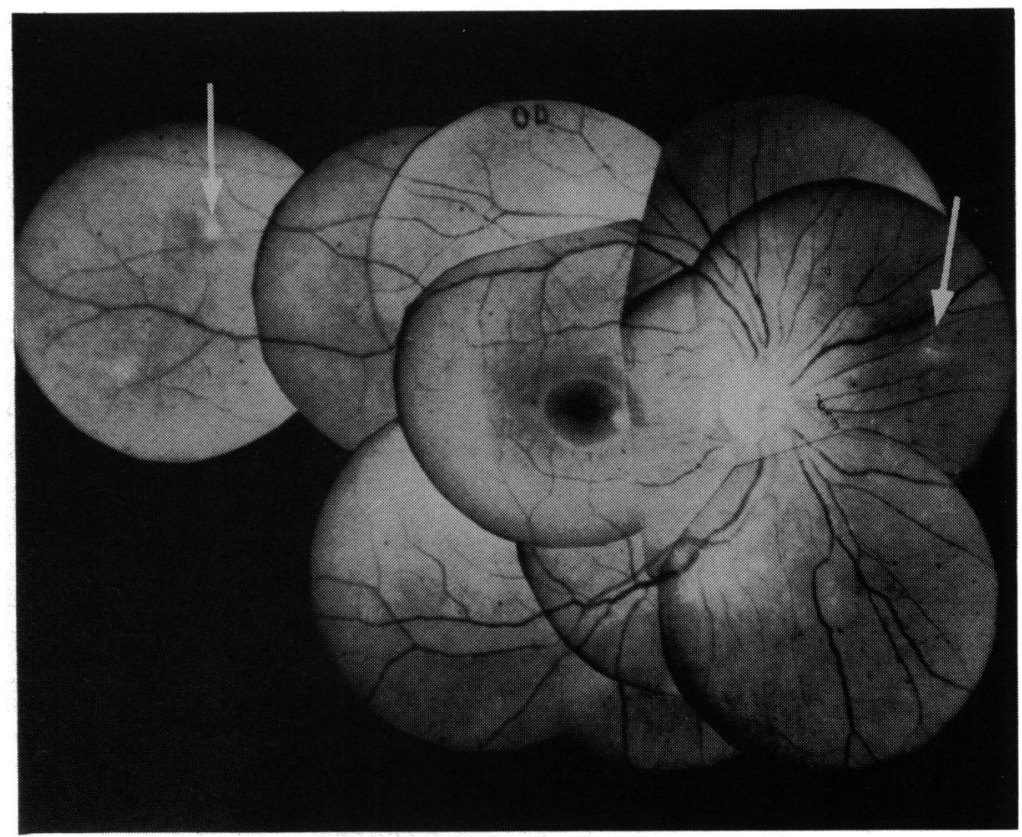

when he presented with portal hypertension associated with stools positive for $S$. mansoni.

Physical examination. No significant changes.

Laboratory tests. The Mantoux test was positive at 1:10000. A brucella test was negative, and a histoplasmin test negative. A chest $x$-ray was normal. Stool examination was negative.

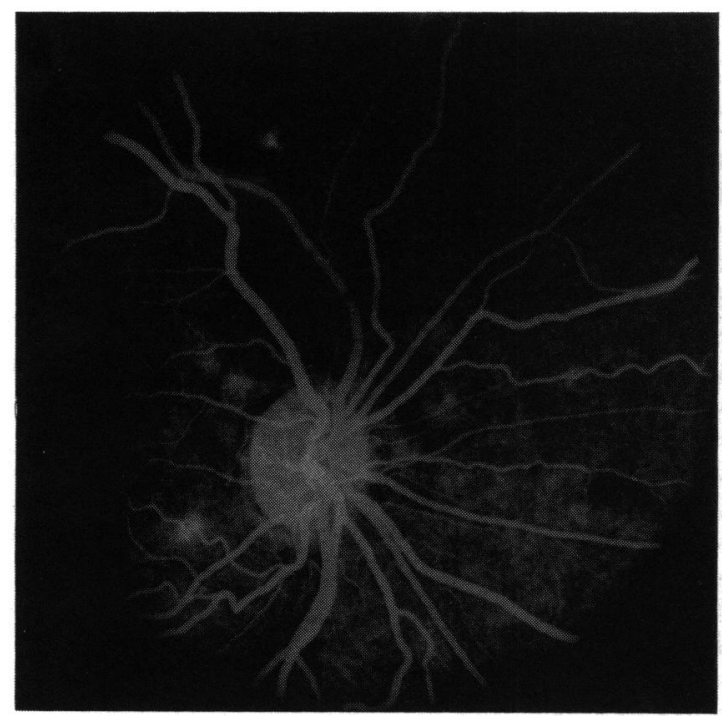

Fig. 5A
Eye examination. Right eye visual acuity was 20/50 with correction, left eye 20/20. The intraocular pressure was $13 \mathrm{mmHg}$ in both eyes. Biomicroscopy of the anterior chamber and anterior vitreous body of both eyes revealed no inflammatory cells. Contact lens biomicroscopy was not done in this case. Indirect binocular ophthalmoscopy (Fig. 6, right eye) of both

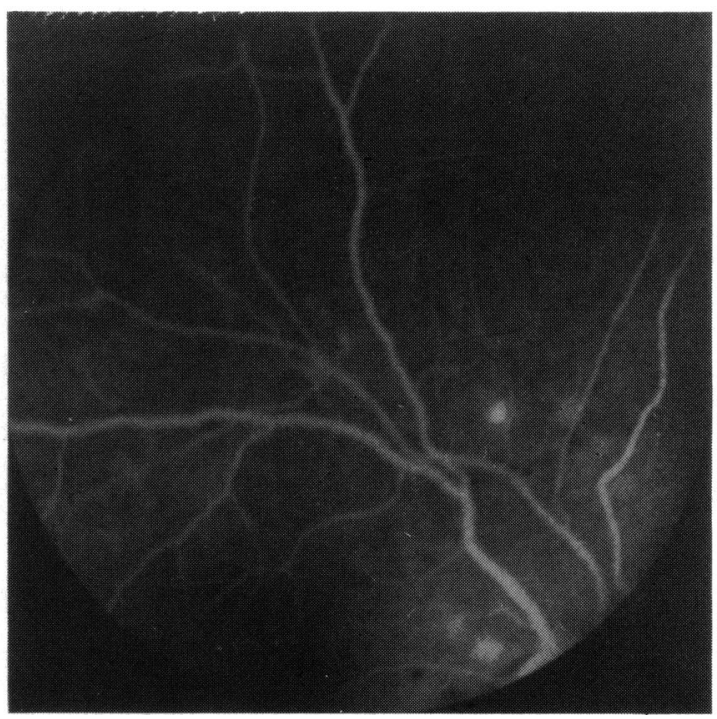

Fig. 5B

Fig. 5 Case 2: A: right eye, fluorescein angioretinography (arteriovenous phase) showing hyperfluorescent nodules. $\mathrm{B}$ : nodules maintaining hyperfluorescence in later phase of the examination. 


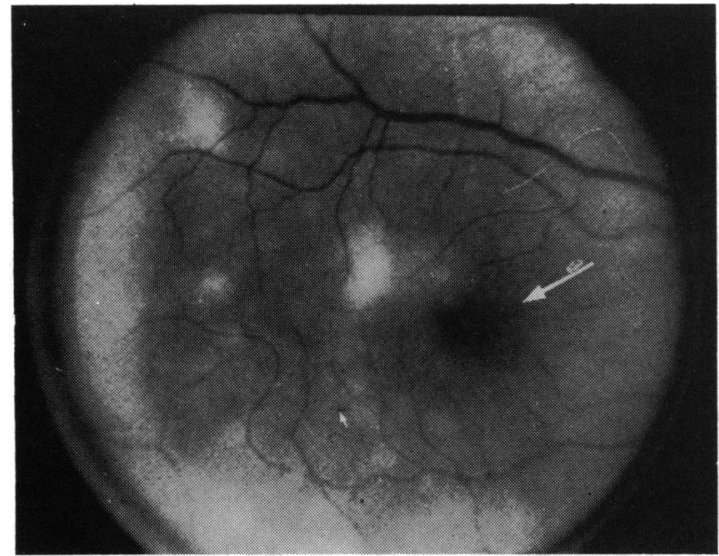

Fig. 6 Case 3: right eye, with whitish medium sized nodules, and striation of the retinal internal limiting membrane in the macular area (arrow).

eyes disclosed numerous yellowish white nodules with irregular distribution. The macula in the right eye presented striations on the internal limiting retinal membrane. Fluorescein angioretinography was not possible in this case.

CASE 4

This case was a 16-year-old male, of mixed colour, admitted to hospital in 1981.

Physical examination. The spleen was enlarged (Boyd type III), towards the median line, hardened, not painful. The liver was not palpable. Cardiac and lung auscultation were normal.

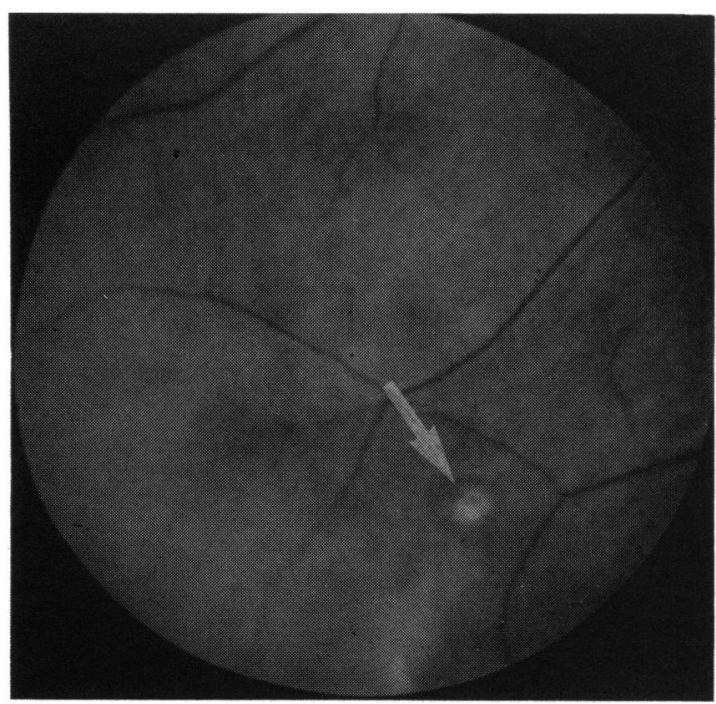

Fig. 7 Case 4: right eye, a whitish nodule with a haemorrhagic halo (arrow).
Laboratory tests. Stool examination was positive for $S$. mansoni. A chest $x$-ray showed signs of pulmonary hypertension and reduction in peripheral base vascularity. Upper gastrointestinal barium radiography showed oesophageal varices. Hepatic biopsy showed granuloma of possible schistosomotic origin.

Eye examination. The visual acuity for both eyes was $20 / 20$. Intraocular pressure was $12 \mathrm{mmHg}$ in both eyes. Biomicroscopy of the anterior chamber and anterior vitreous body revealed no inflammatory cells. Contact lens biomicroscopy was not done in this case. Indirect binocular ophthalmoscopy (Fig. 7, right eye) disclosed small, yellowish white translucent nodules in both eyes. The right eye showed a nodule surrounded by a haemorrhagic halo. Fluorescein angioretinography was not possible in this case.

CASE 5

This case was a 24-year-old male, white, admitted to hospital in 1982.

Physical examination. The liver was $4 \mathrm{~cm}$ below the costal margin, not painful.

Laboratory tests. Stool examination showed $S$. mansoni viable and non-viable ova. Oesophagogastroduodenoscopy showed medium calibre oesophageal varices. A chest $x$-ray was normal.

Eye examination. The visual acuity for both eyes was $20 / 20$. Intraocular pressure was $16 \mathrm{mmHg}$ for both eyes. Biomicroscopy of the anterior chamber and anterior vitreous body revealed no inflammatory signs. With the Goldmann-Busacca contact lens no inflammatory cells were found in the vitreous body in

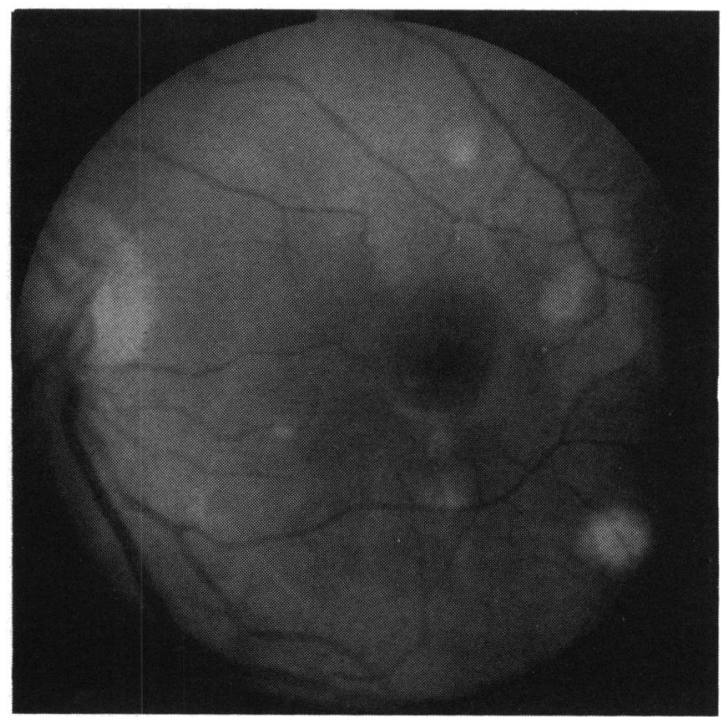

Fig. 8 Case 5: left eye, with large, whitish, irregularly distributed nodules. 


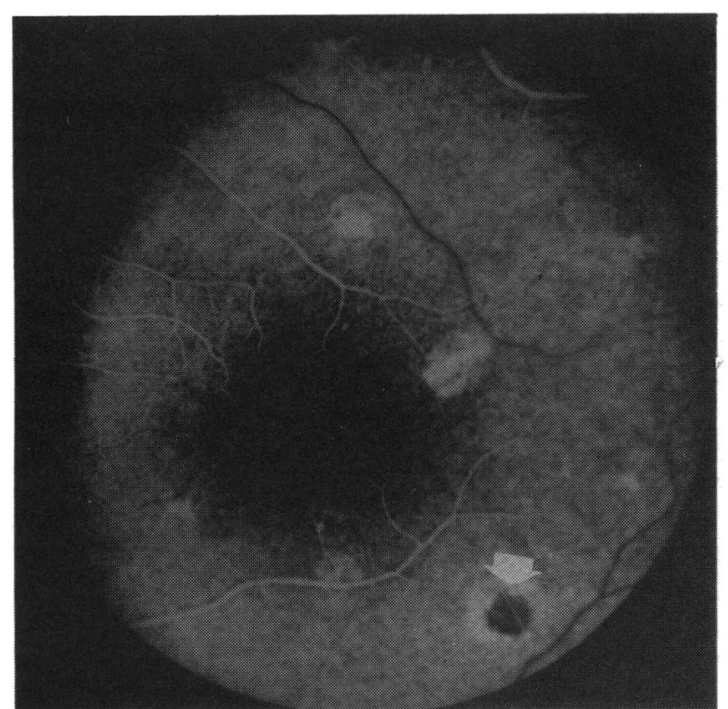

Fig. 9A

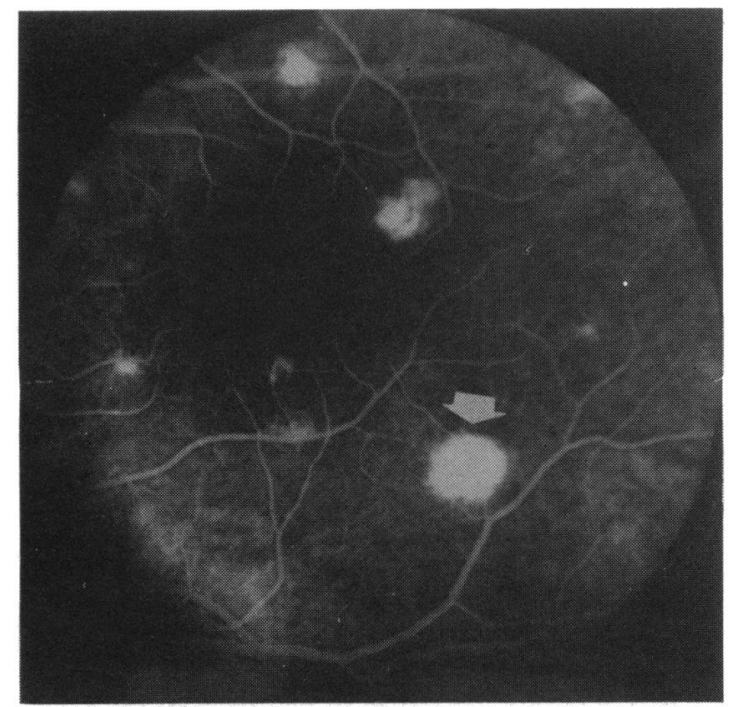

Fig. 9C

either eye. A section of the eye showed nodules (Fig. 1) similar to those in case 1. Indirect binocular ophthalmoscopy disclosed yellowish white nodules of various sizes in both eyes, with irregular distribution and some concentration around the optic nerve and close to blood vessels (Fig. 8, left eye). Fluorescein angioretinography (Figs. 9A, B, C, left eye) of the left eye showed hyperfluorescent nodules in the arterial phase, and a hypofluorescent point surrounded by a hyperfluorescent halo in the lower temporal region. No change in hyperfluorescence was observed in the early arteriovenous phase. In the

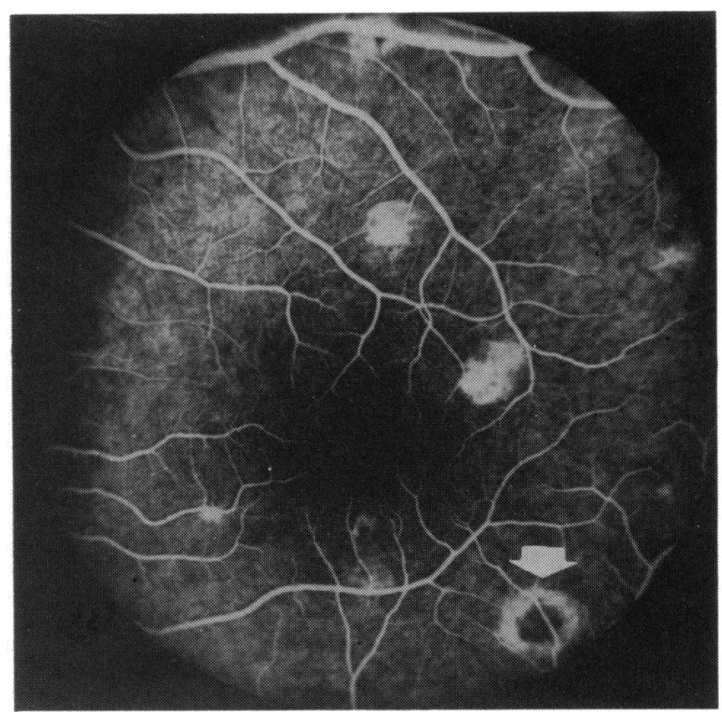

Fig. 9B

Fig. 9 Case 5: A: left eye fluorescein angioretinography (arterial phase) showing hyperfluorescent nodules, and dark hypofluorescent nodule (arrow) with hyperfluorescent halo. B: (arterial-venous phase) maintains similar findings. C: (late phase) with hyperfluorescent nodule (arrow).

Fluorescein angioretinography of the right eye was similar.

late phase the hypofluorescent point became hyperfluorescent. At this point the vein projected towards the vitreous body. Fluorescein angioretinography of the right eye was similar.

\section{Discussion}

These cases suggest that funduscopic changes may occur fairly frequently in hepatosplenic schistosomotic patients. Of 50 patients five were found to have such changes. These were yellowish white translucent nodules of various sizes located in the choroid, 
confirmed by optical section biomicroscopy and fluorescein angioretinography in three of them. In all five cases the anterior segment was not affected, and only case 2 presented a small number of cells in the vitreous body, demonstrating the choroidal location of these lesions.

It was noted that nodules did not interfere with visual acuity if the maculae was not affected. Only case 3 had macular nodules.

A comparison of these funduscopic findings with changes found in similar conditions is the aim of this paper. Our work was hampered by the lack of reported data, probably due to the fact that examination of the fundus is not routine in patients with schisotosomiasis.

Studying a group of military recruits (18-19 years of age) who had contact with river water in the vicinity of Belo Horizonte during training manoeuvers, Oréfice and Brandão (unpublished work) noted that 78 of a total of 130 recruits eliminated $S$. mansoni ova. Clinical and laboratory examinations led to the diagnosis of 39 patients in the acute phase, 17 in the chronic phase, and 22 undefined cases. All had a normal fundus on examination. No patients had the hepatosplenic form of the disease.

Few ocular findings have been attributed to $S$. mansoni. ${ }^{9}$ Uveitis and vascular changes in the retina in patients with stools positive for $S$. mansoni have been described, suggesting a possible association..$^{10-15}$ Non-specific lesions such as retinal haemorrhage and soft and hard exudates were observed in 60 patients with hepatosplenic schistosomiasis, but we were unable to correlate these findings because other systemic changes were present. ${ }^{16}$

Since no histopathological examinations were possible in these cases, the fundus lesions have been analysed by the nature of the changes and the differential diagnosis from other pathological choroidal lesions. The dimension and colour of the choroidal nodules are similar to $S$. mansoni ova granulomas present in other organs of patients with schistosomiasis. We believe that the choroidal nodules are $S$. mansoni ova granuloma. The possible pathways by which $S$. mansoni eggs could reach the eye are discussed in the second part of this paper. ${ }^{8}$

The recent histological finding of a schistosomotic granuloma in the choroid of a patient with hepatosplenic schistosomiasis ${ }^{8}$ confirms the hypothesis of Neves et al. ${ }^{7}$ Another posibility is that these nodules are the morphological changes due to immunocomplex deposits similar to those found in renal glomeruli ${ }^{17}$ and the choroidal plexus ${ }^{18}$ and not an inflammatory reaction to $S$. mansoni ova. However, these mechanisms do not produce micronodular lesions visible on endoscopy.

The fundus lesions we encountered show some similarity to those that occur in chronic miliary tuberculosis. All cases were investigated for this possibility with or without positive Mantoux tests. Clinical study and follow-up allowed us to establish $S$. mansoni as responsible for the fundus lesions.

NOTE. Busacca's terminology was used in biomicroscopy. ${ }^{19}$

We thank Dr Renato Laender and Dr Giambatista Coscarelli for intravenous fluorescein angiography, and Mrs Claudia Lambert for drawing the optic section of the nodule.

\section{References}

1 Pessoa SB, Martins AV. Trematodeos parasitas do sistema sanguineo. Schistosoma mansoni-Histórico-Distribuição Geográfica-Morfologia e Biologia. In: Pessoa SB, ed. Parasitologia Médica. Rio de Janeiro: Guanabara Koogan, 1982: 361-81.

2 McCully RM, Barron CV, Cheever AW. Schistosomiasis. In: Benfered $\mathrm{CH}$, Connor DH, cds. Pathology of tropical and extraordinary diseases. Washington, DC: Armed Forces Institutc of Pathology, 1976: 2: 482-3.

3 Hoffman Jr D. Schistosomiasis research. The strategic plan. New York: Edna McConnell Clark Foundation, 1983: 105.

4 Coutinho.A, Domingues ALC. Esquistossomose mansoni. In: Dani R, Paula Castro L, Perez V, Arabehety JT, eds. Gastroenterologia. Rio de Janeiro: Guanabara Koogan, 1978: 850.

5 Bogliolo L. Fígado e vias biliares. In: Bogliolo L, ed. Patologia. 3d ed. Rio de Janeiro: Guanabara Koogan, 1981: 717.

6 Pitella JEH, Lana-Peixoto MA. Brain involvement in hepatosplenic schistosomiasis mansoni. Brain 1981; 104: 621-32.

7 Neves J, Pedroso ERP, Oréficc F, et al. Esquistossomose pulmonar. III-Forma crônica externa com hipertensão pulmonar e na vigência de hipertensão portal associado a provável coroidite e retinite esquistossomótica. Arq Bras Oftalmol 1978; 41: 215-20.

8 Pittella JEH, Oréfice F. Schistosomotic choroiditis. II. Report of first case. Br J Ophthalmol 1985; 69: 300-2.

9 Cordero Moreno R. Sobre algunas lesiones oculares en la schistosomiasis mansoni. Arch Venez Soc Oto-Rino-Laring 1943; 2: $158-75$.

10 Cecchetto E. Il primo casi di Schistosoma mansoni riscontrato in Europa, con gravi complicazioni oculari. Ann Ottalmol Clin Oculist 1931; 59: 155-8.

11 Andrade C. Esquistossomose. In: Andrade C, ed. Oftalmologica tropical (Sul-Americana). Rio de Janeiro: Rodrigues, Jornal do Correio-Brasil, 1940: 93-101.

12 Machado NR. Esquistossomose mansônica c oftalmologia (nota prévia). Ophthalmol Ibero Americana 1956; 18: 89.

13 Queiroz JM. Aspectos experimentais e clínicos das manifestaçōes oculares da esquistossomosc mansoni. Ophthalmol Ibero Americana 1961; 22: 115-226.

14 Massa MJ, Laurijs L, Wijns (Louvain). Lésions parasitaires de la retine chez une femme bantouc. Bull Soc Belge Ophtalmol 1964; 137: 412-23.

15 Vedy J, Carrica A, Rivaud C, Chanut G, Gravelinc J. A propos d'un cas de rétinite chez un bilharzien. Med Trop (Madr) 1979; 39: 603-7.

16 Lemos E. Alterações retinianas na esquistossomose hepatoesplênica. Rev Bras Oftalmol 1980; 39: 123-8.

17 Hoshino-Schimizu S, Brito T, Kanamura HY, et al. Human schistosomiasis: Schistosoma mansoni antigen detection in renal glomeruli. Trans $R$ Soc Trop Med Hyg 1976; 70: 492-6.

18 Queiroz AC. Lesões da plexo coróide nas esquistossomose mansônica. Arq Neuro-Psiquiatria (Sāo Paulo) 1981:39:317-20.

19 Busacca A. Le fond de l'ocil. In: Busacca A, ed. Manual de biomicroscopie oculaire. Paris: Doin, 1966: 286-323. 